\title{
Study on the Formation of Copyright in Music in Germany and in Russia
}

\author{
Yana Ferran \\ State Institute for Art Studies \\ Moscow, Russia \\ Leipzig University \\ Leipzig, Germany \\ E-mail: ferran.yana@mail.ru
}

\begin{abstract}
The article is devoted to the question of the formation of Russian and German copyright of musical works. It considers the system of privileges as a source of copyright, presents the chronology of the emergence of copyright laws in Russia and Germany in the XIX century. The work also includes an analysis of correspondence between Germany and Russia on copyright issues in connection with the Bern Convention of 1886. The main material for the article was sources and literature from the funds of German and Russian archives and libraries.
\end{abstract}

Keywords-composer; copyright; privilege; law; publisher

\section{INTRODUCTION}

As is known, copyright first arose in relation to works of literature in connection with the improvement of printing in the 15 th century by Gutenberg. The essence of copyright was the protection of publishers from reprints. This protection was carried out by giving publishers authorities privileges to print this or that edition. The origin of copyright in Germany and in Russia is the system of privileges. The first privileges were addressed to publishers. The system of privileges served as the sources of copyright in Russia and Germany. The first privileges were addressed to printers and publishers. According to $\mathrm{Yu}$. Aleksandrovsky, the composer was granted for the first time certain rights in terms of copyright in Nuremberg, on the basis of a law adopted in 1550 and approved in 1623 [1].

In Russia, the first privileges appeared in 1698 under Peter I.Legislative securing of copyright was heavily delayed for reasons of slow formation of the very idea of authorship. There was a perception that written texts do not belong to a specific person, but are a common property (therefore, everyone can read and rewrite them). Only in the 18th century, after Peter's reforms, there was an idea of copyright for a book (but often the need to legislate the authorship of the book did not arise due to the economic unprofitableness of counterfeiting) [2]. Under the Decree of 1771, which established censorship of foreign literature, the privilege was given for printing books in foreign languages to the book seller Hartung, in 1776 - to the booksellers Weitbrecht and Spor for printing foreign and Russian literature. Decree of Catherine II of 1783 destroyed privileges. Until the beginning of the 19th century, there were no prerequisites for the creation of copyright on musical works in Russia.

In Germany, after the perfection of the book and musical press Gutenberg, from the 16th century, the first publishers began to appear, who were exclusively engaged in musical notes. Although the bulk of publications continued to be literary works. Since the 17 th century, we can talk about the publication of music, as we understand it today. Тогда же At the same time, the notion of publishing ownership arose. Since the 18th century, the development of the theory of intellectual property began. Until this idea became the basis of legislation, the protection of musical works was carried out by prohibiting reprints, which, as a result of earlier granted privileges, gradually became legalized. It was publishers who raised the issue of the need for special protection of their products. Legal issues in the field of copyright emerged when the printing of books / book trade began to actively duplicate and distribute "old" and modern works, when copyright became the right of publishers who sought to consolidate their printed powers through privileges. Already in the middle of the 18th century, intellectual property ideas took a firm place in the general legal consciousness, and circa 1790 the term "intellectual property"(german "geistiges Eigentum", "Geisteseigentum") was fixed, connected with the idea of the author's comprehensive rights to his works[3].

From the second half of the 18th century until 1815 in Germany there was a great controversy about reprinting and intellectual property. In the 19th century German music publishers founded a society for mutual protection against piracy. It was created in Leipzig in 1829 under the name "Verein der Deutschen Musikalienhändler" (The Association of German music dealers).

Thus, both in Germany and in Russia, between the invention of the seal and the author's defense, a long historical period has passed.

\section{COPYRIGHT LAWS IN THE 19TH CENTURY}

The sources of copyright in Germany are the union acts and rulings of $1815,1837,1845$, the Prussian Law of 1837 , the Bavarian Law of 1840.In freestanding German lands, the 
rules for copyright protection were completely different. In the first decades after 1815, German jurisprudence failed to develop a generally accepted dogmatic justification for the authors' exclusive rights to their works.

In Russia, the first act that affected the rights of composers was the Regulation of November 13, 1827 "On the rights of writers of dramatic plays and operas taken to represent in the imperial theaters". It recognized the composer's right to remuneration for the public performance of his works. Since that time, the copyright to a musical work has become an independent right, subject to protection in civil laws. In the censorship statute on April 22, 1828, five articles on copyright were first placed, and the Regulations on the rights of authors were published as an annex. It fixed the author's lifelong exclusive right to his works, which passed to heirs or successors for 28 years after his death. On February 4, 1830, the Highest approved opinion of the State Council "On the Rights of Writers, Translators and Publishers" was slightly added to the Statute of 1828: along with the writer/composer, the figure of the publisher and translator appeared, and the term "copyright ownership" was introduced.

Meanwhile, the German Union made efforts to uniformly protect intellectual works in the period from 1815 to 1845 . In the Federal decree of September 5, 1832, was adopted article $18 \mathrm{~d}$ of the Federal Law of Germany, according to which all subjects of individual states of the German Confederation received equal status. It was necessary to observe the principle of the national regime. After the publication of the federal decree of 1832, privileges for matters not regulated by the Federal Assembly were granted in Braunschweig, which mainly concerned musical works or privileges for the heirs of an author. Then came the federal decrees of 1837 , 1838, 1840.The Prussian Law of 1837 and the resolution of the Federal Assembly of June 9, 1845 recognized the basic principles of modern copyright law in Germany: the author's consent to the distribution of his works; protection period 10 or 30 years; author's claim for compensation; prohibition of reprints; punishment for any reprints. Five months before the German decree, in Russia on January 9, 1845 by the decision of the State Council, the legislature "recognized the usefulness of providing equally strong rights to musical property"[cited by:4].In 1857, the Highest approved opinion of the State Council (after the petition of Pushkin's widow N.N. Lanskaya to the Minister of public education of the A.S. Norov), the term of copyright was extended to 50 years after the author's death ${ }^{1}$.

In the 1840s-1860s, German copyright legislation gradually entered the international arena ${ }^{2}$. In 1864 a draft of

The decision to extend the term of literary and "similar artistic and musical property" was argued by the fact that "in Russia, authors, in comparison with foreign ones, have, in general, much less benefits and, consequently, are less rewarded for their works, sometimes combined with various inconveniences and costs $<\ldots$.. "[cited by: 5].

For example, in 1847 the Kingdom of Hanover concluded an agreement with England on the protection of literary and legal property. The treaty confirmed protection against reprints of books, dramatic and musical works. In 1852 an agreement was signed with the French Republic on the protection of property rights for works of literature and art. Article 1 the general German statute on copyright was created.On its basis on June 11, 1870, the North German Confederation issued the first uniform resolution "The law on the copyright of literary works, images, musical compositions and dramatic works" (german, Das Gesetz betreffend das Urheberrecht an Schriftwerken, Abbildungen, musikalischen Kompositionen und dramatischen Werken"), which was adopted on April 16, 1871 as the law of the Reich. Although the law already referred to copyright as a subject of regulation, however, it mainly concerned the idea of prohibiting reprints ${ }^{3}$. The law was adopted at a time when music stores were gaining more and more important economic importance. At the same time, the industry was characterized by strong competitive pressure. It was because of the slowly progressing recognition and disparate development of copyright protection the music publishers competed in reprinting notes. This situation has led to the fact that music publishers have joined forces to form a legal framework. The law of 1870/1871 provided for one feature related to the right of public execution. The musical notes were to carry the so-called stipulated condition to execution (german "Aufführungsrechtsvorbehalt") ${ }^{4}$, so that after buying a music edition the right of public execution still had to be purchased separately. If there was no such reservation in the music edition, the musical work could be performed public without additional permission.

This law of the Prussian Empire replaced the traditional legal construction of "spiritual property" with the notion of "copyright" as such and served as an example for Russian jurists who in the seventies of the 19th century began to depart from the previous interpretation of the legal nature of copyright as a kind of property [ref.7]. At the end of the 19th century, the development of a fundamentally new doctrine of copyright began in Russia. The 1880 s were marked by increased interest in this field. For example, the provisions on liability for violation of the rights of the author, including the composer, were recorded in 1885 in the Penal Code on penal and correctional. In 1898, a draft of a new provision on copyright was created, in 1900 in the Code of Civil Laws were published Rules of ownership of works of science, literature and arts. The main attention in them was paid to the norms of publishing musical works. Article 43 established the possibility of public performance of a work, depending on whether it was published or not. It was said about the admissibility of borrowing someone else's musical material; five articles (46-50) were devoted to the interaction of the composer with foreign publishers. The 1900 statute took a

stated that works of art, namely books, writings, dramatic works, musical compositions, paintings, engravings, drawings, lithographs, sculptures and other literary and artistic works should be protected from reprinting and reproduction. In 1866, two royal patents were issued in Hanover. The first with France on July 19, 1865 concerned the mutual protection of rights to literary products and works of art. June 17, 1866, a second patent was signed with the Kingdom of Belgium, in which the parties postulated not only the mutual protection of rights to works of literature and art, but also trade names[read more:6].

The law was essentially based on a proposal drawn up in 1857 by the Exchange Association of German Book Trade (german "Der Börsenverein des Deutschen Buchhandels"). publisher. 
significant step forward, marking a preparatory stage in the development of the future comprehensive copyright law of 1911.

While the 1900 Regulations became a kind of project for the future reform of copyright in Russia, a similar reform of copyright law in Germany was already implemented in 1901 with the introduction of the "Law on the copyright of works of literature and music" of June 19 (german "Gesetz betreffend das Urheberrecht an Werken der Literatur und der Tonkunst"). With this reform, the author was granted broader rights.

\section{SOLUTION OF COPYRIGHT ISSUES BETWEEN GERMANY AND RUSSIA IN CONNECTION WITH THE BERNE CONVENTION OF 1886}

As you know, the first impetus to the internationalization of copyright occurred on September 9, 1886, when the Berne Convention for the Protection of Literary and Artistic Works was adopted. Germany was among its first participants, Russia did not join the convention. However, in connection with this international agreement between Germany and Russia, the coordination of copyright issues began, which led to the creation of the most complete Russian law" Copyright in literary, musical, artistic and photographic works" of March 20, 1911.During the 25-year period between these two events, an intensive correspondence was conducted between the Stock Exchange of German Booksellers in Leipzig and the Association of Russian Booksellers and Publishers in St. Petersburg, which was published in the "Stock Sheet of German Book Trade" (german "Börsenblatt für die Deutschen Buchhandel").

In the $1890 \mathrm{~s}$, Russia was active in the development of copyright legislation. This is evidenced by documents of the famous Russian music publisher B.P. Yurgenson, in which several major events are mentioned. Two reports were read at the First Congress of Russian Publishers in 1895:about the approval of the society of Russian composers and publishers and about the illegal copying of musical works. A year later, a congress of representatives of 8 countries was held in Moscow, where the issue of the illegal importation from abroad of reprints of musical works of Russian composers was considered. In 1898, 32 countries took part in the congress; The Russian Draft Law on the Copyright of Music was discussed. Finally, in 1899, Russia took part in the International Congress on Copyright in Dresden, presenting the report "About the condition of copyright in musical works in Russia" in German [8].

Active correspondence between Germany and Russia began in 1908.May 6, Vienna Music Publishing House "W. Karczag \& C. Wallner" filed a complaint to the Board of the Exchange Association of German booksellers in Leipzig against the Moscow firm "P. Yurgenson". The letter said that the firm "P. Yurgenson" illegally reprinted the waltz "Red Roses" from the operetta "The husband with three wives "by Franz Lehar and sold it on a commission basis to the firm "E. Wende \& Co." in Warsaw. May 9 was followed by a response letter: "...the music publishing house, P. Yurgenson "in Moscow is not a member of the Exchange
Union, and therefore we have no way to influence them or do anything against them. We recommend that you contact the Association of German Music Stores in Leipzig" [9]. Many German publishers were concerned that the reprinting of their works in Russia is illegal and can not be controlled. Numerous requests to resolve this issue came from German publishers to the Leipzig Stock Exchange ${ }^{5}$. The Union referred to the fact that "...there is no literary agreement between Germany and Russia, and Russia did not join the Berne Literary Convention of September 9, 1886. ... In accordance with this, it is impossible to trace...the reprint in Russia" (letter to the printing house and the publishing house "U. E. Sebald", Nuremberg, June 4, 1908) [9].From this moment and throughout 1909, the topic of Russia's accession to the Berne Convention and the draft Russian copyright law were discussed.

The letter from the Board of the Union of German Booksellers in Leipzig to the publisher Erich Ehlermann in Dresden on July 24, 1908, said: "From the letter of the Leipzig Chamber of Commerce on July 4 this year it became known that the Russian government is negotiating an agreement on copyright with Germany $\langle\ldots>$. The government also took the first steps to draft a law on copyright and its submission to the Duma; Ref. Stock Sheet No. 57 of March 9, 1907 and No. 152 of July 3, 1908" [9] $]^{6}$.

From the letter of the Russian Society of Publishers and Booksellers St. Petersburg to the Stock Exchange of German Booksellers in Leipzig of August 25, 1908: "The Russian government has recently opposed legal protection of copyright for foreign works, but in some cases PRINCIPALLY approved the conclusion of agreements with individual states. Since this final approval gives no sufficient material from which one could conceive that such deals can soon be brought to life, an entry by the Börsenvere in des Deutschen Buchhändler would have been requested, referring to the trade agreement between Russia and Germany in $1904^{7 / "[9] . ~}$

Since the end of 1908, the weekly magazine "Stock Sheet of German Book Trade" published information on Russian measures to adopt the new law. One of the earliest articles was called" Scientific, literary, artistic and book dealer news from Russia" и and was written by a permanent correspondent of the "Stock Sheet" by W. Henckel (No.294, December 18, 1908). April 20, 1909 from St. Petersburg it was reported that "The State Duma, which met again today, adopted a bill on copyright protection in one reading. ....Minister of Justice stated that the project's goal is to protect Russian authors. In accordance with trade

See, for example, letters from publishers "Robert Cordes" (Kiel, December 3, 1907), "Ullstein \& Co" (Berlin, January 15, 1909) etc.

The letter also mentioned that the Russian government is unfavorably inclined towards joining the Berne Convention. According to other sources, only journalists resist this, and the agreement will anyhow be achieved. This topic was raised at the last congress of publishers.

This refers to the Commercial contract and shipping contract of July 15,1904 . It referred to the Russian government's obligation to enter into negotiations with the German government to conclude an agreement on mutual protection of copyright for works of literature, art and photography for a period of 3 years beginning on March 1, 1906. 
agreements, Russia undertakes to conclude a literary convention with Germany, Austria-Hungary and France. However, this does not correspond to Russia's dignity to grant rights to foreign authors, while Russian authors do not have such rights" (Nr. 89, April 20, 1909) [9].Soon, on April 28 , the office of the Union of German Booksellers in Leipzig sent a letter to the St. Petersburg Board of the Association of Russian Booksellers and Publishers asking to send the text of the copyright law to Leipzig. The German side was very interested in the fact that the Russian copyright law was brought to the attention of the German book trade in the "Stock Sheet". May 7, 1909 was followed by a response from St. Petersburg:"...text of the Copyright Law and the debate in the State Duma ...is published in the "Knizhnyy vestnik".... Your regular correspondent, Mr. Henckel, would probably best describe this article in German translation". On May 25, the Stock Exchange of German Booksellers in Leipzig, "very concerned about this copyright law" [9], sent an order to Mr. Henckel to Munich to translate the text of Russian law into German and provide it for publication in "Stock Sheet". The next day, Henckel reported that the text of the new Copyright Law in Russia had not yet been published, but promised to immediately write to St. Petersburg and, after receiving the text, begin the translation. The perseverance of the Stock Exchange continued, and on June 15 the union again asked Henckel for a reply whether he had received the text from St. Petersburg and whether the transfer had begun. Finally, in the "Stock Sheet" were published two articles "From the Russian copyright law" (No.138, June 18, 1909; No.140, June 21, 1909).

The main further publications on the issue of Russian copyright in the Journal of the Association of German Book Trade were the following:

- "Draft of the Russian law on copyright" (No.160, July 14, 1909);

- "The First All-Russian Book Dealers and Publishers Congress in St. Petersburg, 13 to 18 July 1909" (No.189, August 17, 1909);

- "From Russia. About the Literar Convention. By Th. Ettinger (St. Petersburg)" (No.241, October 16,1909);

- "Russia and international treaties for the protection of literary copyright" (No.257, November 4, 1909);

- "The term of protection of copyright in Russia" (No.106, May 11, 1910);

- "Acceptance of a Russian copyright law with copyright protection of foreigners" (No.55, March 7, 1911);

- "Copyright protection of foreigners in Russia" (No.65, March 20, 1911);

- "The new Russian Copyright Law of March 20, 1911" (No.122, May 29, 1911);

- "Advice to foreign publishers who conclude contracts with Russian authors and translators under the
Copyright Law of 20 March 1911" (No.146, June 27, 1911);

- “Copyright Law of 20 March 1911” [„Copyright in literary, musical, artistic and photographic works"] (No.190, August 17, 1911, No.191, August 18, 1911, No.192, August 19, 1911, No.193, August 21, 1911)[9, 10].

As you can see, the Russian copyright law of 1911 was adopted after long preparatory work and sharp debate in the legislative chambers. It became the most complete normative document regulating the scope of copyright and entrenched the term "copyright". Six months later, on September 28, 1911, in Office for National Justice negotiations began on the topic "The Basics of the German-Russian Copyright Treaty". The Russian-German literary convention was published in the "Stock Sheet of German Book Trade" in 1912 (No.120, May 25; No.126, June 8).

\section{CONCLUSION}

As can be seen from the above, the initial stage in the development of copyright was the system of privileges granted to the publisher. Note that in Germany the publisher did not receive the original right, but rather had a derivative right received from the author. In Russia there was a reverse situation. Copyright here appeared in favor of the publisher, not the author.

The transition from the publisher's privilege to the author's right was connected with the development of the very idea of authorship. Speaking of music, until the 18th century the composers were in the service of the nobility and the church, where they performed different tasks and the composition was only a part of their activity. Thus, the authors were socially provided. The situation dramatically changed with the appearance of a bourgeois musical culture. Since in the new public musical life a permanent position was no longer given to the composer, his economic independence was to be regulated in a different way. It is here that copyright comes into play, which can guarantee the composer autonomy, giving him a legitimate ownership of his intellectual achievements.

Throughout the 19th century, both in Germany and in Russia, there was a process of developing legislative norms regarding copyright on musical works. Russian legislation in the 19 th century included decrees of $1827,1828,1830,1845$, 1857 , and 1885 . The main provisions of copyright law were taken from the legislation applicable to literary works. The rights of composers were formalized in the same way as writers' rights ${ }^{8}$. The key landmarks of German legislation were the federal decrees and local laws of 1815, 1837, 1838, $1840,1845,1870 / 1871$.A major copyright reform took place in Germany in 1901, in Russia — a decade later.

The revision and improvement of the laws was greatly facilitated by the international event - the Berne

\footnotetext{
8 So, in parallel with the norms on literary property, the term of the exclusive right to musical works was established, forms of responsibility for the misuse of musical compositions, etc., were developed.
} 
Convention of 1886.The Exchange Association of German booksellers in Leipzig played an important role in spreading the norms of copyright and resolving disputes in this sphere. The association of booksellers and publishers of St. Petersburg often contacted this organization. Correspondence between Leipzig and St. Petersburg reflected the main claims and problems of copyright law of the time.

\section{REFERENCES}

[1] Yu. Aleksandrovsky. "Copyright. Law of March 20, 1911. Historical sketch, legislative motives and explanations", St. Petersburg: The Association for the Issuance of New Laws, the printing house of the joint-stock company "Word", 1911, p. 4.

[2] A. Reitblat. "How Pushkin became a genius: Historical and sociological essays on the book culture of the Pushkin era", Moscow: New literary review, 2001, pp. 108-109.

[3] L. Gieseke. "From privilege to copyright - the development of copyright in Germany until 1845", Göttingen: Schwartz, 1995,p. 115.

[4] B. Yurgenson. "Copyright in musical works", Moscow: "The Polygraphist himself", 2012, pp. 30-31.

[5] S. Pereselenkov. "Pushkin in the history of the legal provisions on copyright in Russia" / Pushkin and his contemporaries: Materials and Research, St. Petersburg, 1909. Issue 11,p.60.

[6] Th. Gergen. "About the copyright of Hanover in the 18th and 19th centuries" /Journal of the Savigny Foundation for history of law. German Department, 125, 2008, 1, pp. 194-195.

[7] N. Dotsik. "Copyright in Russia", thesis for PhD degree, Moscow, 2008.

[8] B. Yurgenson. Appendix to the questionnaire / Personal archive of B.P. Yurgenson.

[9] Saxon State Archives Leipzig. 21765 Stock exchange of German booksellers Leipzig, Nr. 204.

[10] Saxon State Archives Leipzig. 21765 Stock exchange of German booksellers Leipzig, Nr. 205. 